\title{
Lipid Treatment Assessment Project (L-TAP) Study : a survey in 13 cities in Indonesia to evaluate the percentages of dyslipidemic patients achieving NCEP LDL-C target goals after treatment
}

\author{
Rinambaan Willem Mamentu Kaligis, Harmani Kalim
}

\begin{abstract}
Abstrak
Berbagai uji klinik telah membuktikan bahwa penurunan kadar LDL-C sangat bermanfaat baik untuk pencegahan PJK primer maupun sekunder. Meskipun demikian di Amerika Serikat banyak penderita dislipidemia yang tidak diobati menurut petunjuk pelaksanaan yang dibuat NCEP. Pada tahun 1996 di Indonesia telah dibuat petunjuk pelaksanaan penanggulangan dislipidemia untuk pencegahan PJK oleh PERKI. Sampai saat ini pengobatan dislipidemia belum diketahui dengan pelaksanaannya di tempat praktek dokter. Tujuan penelitian adalah menentukan persentase penderita dislipidemia yang mencapai target LDL-C menurut NCEP setelah mendapat terapi minimal 3 bulan. Studi ini dilakukan dengan cara survei potong lintas yang mengikut sertakan dokter yang biasa mengobati penderita dislipidemia di 13 kota di Indonesia. Dokter yang ikut serta dalam penelitian diminta untuk mengisi kuesioner mengenai petunjuk NCEP dan mengisi formulir pencatatan kasus untuk setiap penderita. Terdapat 188 dokter (dari 400 yang diundang) berpartisipasi dalam survei ini dan mengikut sertakan 1420 penderita yang mendapat terapi statin (1082 orang), fibrat (301 orang), kombinasi obat (14 orang) dan non farmakologik 23 orang. Secara keseluruhan terdapat $49 \%$ penderita yang berhasil mencapai target kadar LDL-C yang berkisar dari $14.8 \%$ pada penderita PJK $43.6 \%$ pada penderita risiko tinggi dan 73.0 $\%$ pada penderita risiko rendah. Dibanding dengan terapi lain, penderita yang mendapat statin lebih banyak yang mencapai target kadar LDL-C yaitu keseluruhan penderita $55 \%$, golongan risiko rendah $78 \%$, risiko tinggi $50 \%$ dan PJK $19 \%$. Hanya $14 \%$ dari dokter yang ikut penelitian memakai target kadar LDL-C seperti dalam petunjuk pelaksanaan NCEP. Kesimpulan : sebagian besar penderita dislipidemia yang diobati di praktek rutin tidak mencapai kadar target LDL-C. Banyak dokter yang belum memakai NCEP. (Med J Indones 2001; 10: 103-9)
\end{abstract}

\begin{abstract}
Clinical trials have demonstrated significant benefit from low density lipoprotein cholesterol (LDL-C) lowering for primary and secondary prevention of cardiovascular disease. In the US, it is well recognized that a substantial number of hypercholesterolemic patients were not treated to the LDL-C goals recommended by the National Cholesterol Education Program (NCEP) guidelines. In 1996, the Indonesian Heart Association (PERKI) has issued guidelines recommending goals for screening and lipid treatment in Indonesia adopted from NCEP guidelines; however, the frequency of undertreatment in Indonesia is not known. The objective of this study was to determine the percentage of patients treated with lipid-lowering therapy who reached LDL-C goals as defined by NCEP guidelines in routine clinical practice. This was a cross-sectional survey targeted physicians who regularly treated dyslipidemic patients in 13 cities in Indonesia. Participating doctors were asked on their awareness of NCEP guidelines and to complete the case record form ( $C R F)$ of the enrolled patients. One-hundred and eighty-eight (188) out of four hundreds (400) physicians who were invited, have participated in this study. Among the evaluable 1420 CRF, 1082 patients received statins, 301 used fibrates, 14 patients used combination drugs, and 23 others received non-drug treatments only. Success rates on achieving target LDL-C in low-risk, highrisk, and CHD groups were $73.0 \%, 43.6 \%$, and $14.8 \%$, respectively. Overall success rate in patients using statins was $55.1 \%$, while in low-risk group, high-risk group, and CHD patients, the success rates with statin were $77.8 \%, 50.1 \%$, and $18.6 \%$, respectively. Atorvastatin showed the highest success rate $(77,4 \%)$ if compared to other statins. Only $14 \%$ of physicians were knowledgeable about the NCEP goals. Conclusion : A large number of dyslipidemic patients who were on lipid-lowering therapy were not achieving the recommended $L D L-C$ target levels. Success rates were lower in CHD patients and high risk group. Atorvastatin seemed more effective in lowering the LDL-C to target levels. There are still many physicians in Indonesia who do not aware about the NCEP guidelines and LDL-C treatment goals. (Med J Indones 2001; 10: 103-9)
\end{abstract}

Keywords: lipid treatment assessment project (L-TAP), dyslipidemia, coronary heart disease (CHD) risk, routine practice

Department of Cardiology, Faculty of Medicine, University of

Indonesia, Harapan Kita Hospital/National Cardiac Center,

Jakarta, Indonesia 
12 weeks prior to enrollment were excluded, as well as those who had an acute infection that required current antibiotic therapy or a recent or an abrupt change in their usual diet, exercise and body weight within the preceeding month. Women who were pregnant, breast-feeding, or $\leq 6$ months post partum were also excluded.

\section{Lipid Profile Determination}

Lipid profile information (serum level of total cholesterol, LDL-cholesterol, HDL-cholesterol, and triglycerides) at baseline and after treatment was taken from individual patients medical record. Initial lipid profile has been used as the basic for the investigators to establish the diagnosis of dyslipidemia and to begin treatment. Lipid profile post-treatment was lipid concentrations after a minimum of 3-months of treatment. Blood samples were sent to Prodia Laboratory for lipid profile measurements. Total cholesterol, HDL-C and triglycerida serum levels were determined by chodpap enzymatic immuno-assay method using automatic photometer Hitachi equipment. LDL-C was calculated based on Friedewald's formula : LDL-C = total cholesterol - HDL-C - Triglycerida / 4.

\section{Data Analysis}

The primary study end-point was the proportion of patients on lipid-lowering therapy who achieved LDL-C target levels as defined by the NCEP guidelines. Treatment was successful if the LDL-C level after treatment reached the NCEP target level or lower.
Descriptive statistic of patients and investigators demographics, lipid profiles and success rates are presented. Analytical statistics was used to compare the success rates among risk groups using chi-square test and analysis of variance (ANOVA).

\section{RESULTS}

\section{Investigators Demographics}

One hundred eighty eight out of 400 physicians who were invited has participated in this study. Most of the them were males $(74 \%)$ and practiced as general practitioners $67 \%$, internist $15 \%$, cardiologist $5 \%$, neurologist $3 \%$ and other specialties $10 \%$. The mean age was 47.9 years with mean years practice of 23 years. Only $14 \%$ of investigators answered the questionnaires correctly which indicated their knowledge on NCEP guidelines.

\section{Patients Demographics}

There were 1633 case report forms obtained with complete lipid profile from 13 cities. Because of incomplete data on treatment and patients demographics, 213 forms were excluded from the analysis.

Among 1420 evaluable patients, there were 366 patients in low-risk group, 939 patients in high-risk groups, and $115 \mathrm{CHD}$ patients. As many as $98.4 \%$ of patients received lipid-lowering drugs whereas $1.6 \%$ of patients underwent dietary therapy and exercises only (Table 1)

Table 1. Patient's demographics and treatment

\begin{tabular}{|c|c|c|c|c|c|c|c|}
\hline \multirow[t]{2}{*}{ Risk Group } & \multirow[t]{2}{*}{$\begin{array}{c}\text { Mean Age } \\
(\mathrm{SD} \text { years })\end{array}$} & \multirow[t]{2}{*}{$\begin{array}{c}\text { Sex } \\
\text { (male) }\end{array}$} & \multicolumn{5}{|c|}{ Number of patients and drugs used } \\
\hline & & & Statins & Fibrates & Combination & Non-Drugs & Total \\
\hline Low-risk & $43.1 \pm 9.6$ & $51.3 \%$ & 293 & 65 & 5 & 3 & 366 \\
\hline High-risk & $52.4 \pm 10.1$ & $61.0 \%$ & 703 & 211 & 7 & 18 & 939 \\
\hline CHD & $54.3 \pm 11.5$ & $59.6 \%$ & 86 & 25 & 2 & 2 & 115 \\
\hline Over-all & $50.3 \pm 10.9$ & $58.4 \%$ & 1082 & 301 & 14 & 23 & 1420 \\
\hline
\end{tabular}

Low-risk : No CHD, < 2 risk factors, High-risk: No CHD, $\geq 2$ risk factors, $C H D$ : Coronary Heart Disease

Success Rate by risk groups 
There were $48.8 \%$ of overall patients who reached target LDL-C goals. The mean levels of LDL-C after treatment in patients who reached target goals and those who did not reach target-levels were shown in table 3 . The highest success rate was shown in lowrisk group $(73.0 \%)$, whereas the lowest success rate was found in patients with CHD patients group (14.8\%) (Table 2).

The mean levels of LDL-C after treatment among high risk and CHD patients who did not reach target LDL-C were in fact still higher than the level for initiating drug treatment as recommended by NCEP.

\section{Success rate by treatment}

Among patients using statins, $55.1 \%$ patients could reach the LDL-C target level. This was the highest if compare to other treatment (Tabel 3).

Tabel 3 shows success rates by treatment and by risk group. More patients who received statin achieved LDL-C target goals compared to other class of lipid lowering drugs for over all patients and for every risk group of patient.

Success rate by risk and by drug among patients who received statin for each individual drug was : $31.0 \%$ for fluvastatin, $35.6 \%$ for lovastatin, $25.5 \%$ for pravastatin, $40.6 \%$ for simvastatin and $77.4 \%$ for atorvastatin.

Table 2. Success rates and Mean LDL-C levels after treatment within risk groups

\begin{tabular}{|c|c|c|c|c|c|c|}
\hline \multirow[t]{2}{*}{$\begin{array}{c}\text { Risk } \\
\text { Category }\end{array}$} & \multirow[t]{2}{*}{$\mathrm{N}$} & \multirow[t]{2}{*}{$\begin{array}{l}\text { Success } \\
\text { rates }(\%)\end{array}$} & \multicolumn{2}{|c|}{ Mean LDL-C (mg/dL) after treatment } & \multicolumn{2}{|c|}{$\begin{array}{l}\text { NCEP } \\
\text { recommendation on LDL-C level } \\
(\mathrm{mg} / \mathrm{dl})\end{array}$} \\
\hline & & & $\begin{array}{l}\text { Patients Reaching } \\
\text { Target Levels }\end{array}$ & $\begin{array}{c}\text { Patients Not Reaching } \\
\text { Target Levels }\end{array}$ & $\begin{array}{c}\text { Initiation of } \\
\text { drug treatment }\end{array}$ & Target goal \\
\hline Low-risk & 366 & 73.0 & $\begin{array}{c}123.7 \pm 24.9 \\
(\mathrm{~N}=267)\end{array}$ & $\begin{array}{c}182.7 \pm 24.8 \\
(N=99)\end{array}$ & $\geq 190$ & $\leq 160$ \\
\hline High-risk & 939 & 43.6 & $\begin{array}{c}111.6 \pm 17.6 \\
(N=409)\end{array}$ & $\begin{array}{c}161.9 \pm 27.8 \\
(N=530)\end{array}$ & $\geq 160$ & $\leq 130$ \\
\hline CHD & 115 & 14.8 & $\begin{array}{c}98.4 \pm 28.4 \\
(\mathrm{~N}=17)\end{array}$ & $\begin{array}{c}158.0 \pm 44.6 \\
(N=98)\end{array}$ & $\geq 130$ & $\leq 100$ \\
\hline
\end{tabular}

Low-risk : No CHD, $<2$ risk factors, High-risk : No CHD, $\geq 2$ risk factors, CHD : Coronary Heart Disease

Table 3. Success rate by treatment

\begin{tabular}{|c|c|c|c|c|c|c|c|c|}
\hline & \multicolumn{2}{|c|}{ Statin } & \multicolumn{2}{|c|}{ Fibrates } & \multicolumn{2}{|c|}{ Combination } & \multicolumn{2}{|c|}{ Non-Drugs } \\
\hline & $\mathrm{N}$ & $\begin{array}{c}\text { Success } \\
(\%)\end{array}$ & $\mathrm{N}$ & $\begin{array}{c}\text { Success } \\
(\%)\end{array}$ & $\mathrm{N}$ & $\begin{array}{c}\text { Success } \\
(\%)\end{array}$ & $\mathrm{N}$ & $\begin{array}{c}\text { Success } \\
(\%)\end{array}$ \\
\hline Low-risk & 293 & $\begin{array}{c}228 \\
(77.8)^{\wedge}\end{array}$ & 65 & $\begin{array}{c}35 \\
(53.8)^{\wedge}\end{array}$ & 5 & $\begin{array}{c}2 \\
(40)\end{array}$ & 3 & $\begin{array}{c}2 \\
(66.7)\end{array}$ \\
\hline High-risk & 703 & $\begin{array}{c}352 \\
(50.1) \#\end{array}$ & 211 & $\begin{array}{c}52 \\
(24.6) \#\end{array}$ & 7 & $\begin{array}{c}2 \\
(28.6)\end{array}$ & 18 & $\begin{array}{c}3 \\
(16.7)\end{array}$ \\
\hline CHD & 86 & $\begin{array}{c}16 \\
(18.6)\end{array}$ & 25 & $\begin{array}{c}1 \\
(4.0)\end{array}$ & 2 & $\begin{array}{c}0 \\
(0)\end{array}$ & 2 & $\begin{array}{c}0 \\
(0)\end{array}$ \\
\hline Overall & 1082 & $\begin{array}{c}596 \\
(55.1)^{*}\end{array}$ & 301 & $\begin{array}{c}88 \\
(29.2)^{*}\end{array}$ & 14 & $\begin{array}{c}4 \\
(28.6) \\
\end{array}$ & 23 & $\begin{array}{c}5 \\
(21.7)\end{array}$ \\
\hline
\end{tabular}

Low-risk: No CHD, < 2 risk factors, High-risk : No CHD, $\geq 2$ risk factors, CHD : Coronary Heart Disease

$* P<0.001$ (significant), ^ $P<0.001$ (significant), \#P<0.001 (significant) 
Table 4. Mean LDL-C levels before and after treatment by treatment groups

\begin{tabular}{lcccc}
\hline \multicolumn{1}{c}{ Mean LDL-C levels } & $\begin{array}{c}\text { Statins } \\
(\mathrm{N}=1082)\end{array}$ & $\begin{array}{c}\text { Fibrates } \\
(\mathrm{N}=301)\end{array}$ & $\begin{array}{c}\text { Combination } \\
(\mathrm{N}=14)\end{array}$ & $\begin{array}{c}\text { Non-Drug } \\
(\mathrm{N}=23)\end{array}$ \\
\hline Initial $(\mathrm{mg} / \mathrm{dL})$ & $191 \pm 50^{*}$ & $184 \pm 37^{*}$ & $183 \pm 28$ & $190 \pm 42$ \\
Post treatment $(\mathrm{mg} / \mathrm{dL})$ & $137 \pm 36^{\wedge}$ & $152 \pm 31^{\wedge}$ & $155 \pm 24$ & $172 \pm 45$ \\
\hline
\end{tabular}

${ }^{*} p<0.05$ (significant), ^ $p<0.001$ (significant)

\section{Lipid Profile}

Patients who received statins had higher mean baseline LDL-C $(191+51 \mathrm{mg} / \mathrm{dl})$ as compared to those who were given fibrates $(184 \pm 37 \mathrm{mg} / \mathrm{dl})$. However, mean LDL-C level after treatment was lower in those treated with statins rather than patients treated with fibrates $(137 \pm 36 \mathrm{mg} / \mathrm{dl}$ vs $152 \pm 31$ $\mathrm{mg} / \mathrm{dl}$ )

The difference of initial mean LDL-C values varied among statin group. Initial mean LDL-C value in atorvastatin group was significantly higher than inital mean LDL-C value in simvastatin, lovastatin, and pravastatin, but not in fluvastatin group. After treatment, the mean LDL-C value in atorvastatin group was significantly different from the initial value. This value was also significantly lower than other statins (Tabel 5)

\section{Drug Dosage}

It is shown in Tabel 6, that most patients received the initial or low doses of statins. They were treated with atorvastatin $10 \mathrm{mg}$, pravastatin $20 \mathrm{mg}$, pravastatin 10 $\mathrm{mg}$, simvastatin $10 \mathrm{mg}$, lovastatin $20 \mathrm{mg}$, and fluvastatin $40 \mathrm{mg}$.

Table 5. Mean LDL-C levels before and after treatment within statin groups

\begin{tabular}{lccccc}
\hline Mean LDL-C levels & $\begin{array}{c}\text { Fluvastatin } \\
(\mathrm{N}=58)\end{array}$ & $\begin{array}{c}\text { Lovastatin } \\
(\mathrm{N}=45)\end{array}$ & $\begin{array}{c}\text { Pravastatin } \\
(\mathrm{N}=282)\end{array}$ & $\begin{array}{c}\text { Simvastatin } \\
(\mathrm{N}=133)\end{array}$ & $\begin{array}{c}\text { Atorvastatin } \\
(\mathrm{N}=563)\end{array}$ \\
\hline Initial (mg/dL) & $187 \pm 57$ & $179 \pm 33$ & $187 \pm 39$ & $180 \pm 38$ & $197 \pm 57^{*}$ \\
Post treatment (mg/dL) & $159 \pm 36^{\wedge}$ & $154 \pm 30^{\wedge}$ & $160 \pm 34^{\wedge}$ & $153 \pm 36^{\wedge}$ & $118 \pm 27^{* \wedge}$ \\
\hline
\end{tabular}

${ }^{*} p<0.05$ (significant), ${ }^{\wedge}<0.001$ (significant)

Table 6. Dosages of statin in the study $(\mathrm{N}=1082)$

\begin{tabular}{|c|c|c|c|c|c|c|}
\hline & No data & $5 \mathrm{mg}$ & $10 \mathrm{mg}$ & $20 \mathrm{mg}$ & $40 \mathrm{mg}$ & Total \\
\hline Fluvastatin & $2(1.9 \%)$ & & $6(10.2 \%)$ & $17(29.4 \%)$ & $34(58.6 \%)$ & $58(100 \%)$ \\
\hline Lovastatin & $4(8.9 \%)$ & & $9(20.0 \%)$ & $26(57.8 \%)$ & $6(13.3 \%)$ & $45(100 \%)$ \\
\hline Pravastatin & $6(2.1 \%)$ & $2(0.7 \%)$ & $132(46.8 \%)$ & $139(49.3 \%)$ & $3(1.1 \%)$ & $282(100 \%)$ \\
\hline Simvastatin & $8(6.0 \%)$ & & $81(60.9 \%)$ & $25(18.8 \%)$ & & $133(100 \%)$ \\
\hline Atorvastatin & & & $528(93.8 \%)$ & $35(6.2 \%)$ & & $563(100 \%)$ \\
\hline
\end{tabular}




\section{DISCUSSION}

The NCEP guidelines have defined LDL-C target levels for patients with dyslipidemia in order to reduce the risk of new or recurrent CHD.

Our data has shown that, like in the United States, many dyslipidemic patients failed to reach the NCEP target goals after treatment. The overall success rate in this study was only $48.8 \%$ for all-risk groups. This was higher than the rate of US L-TAP study in 1996 , which showed a success rate $38.4 \% .{ }^{15}$ Another study in the United States, The Estrogen / Progestin Replacement in postmenopausal women with CHD (HERS) Study, reported that $63 \%$ of patients did not reach LDL-C level below $130 \mathrm{mg} / \mathrm{dL}$ and $91 \%$ did not reach LDL-C level below $100 \mathrm{mg} / \mathrm{dL} .{ }^{16}$ In this current study, $85.1 \% \mathrm{CHD}$ patients failed to reach the LDL- target level. This indicates that most patients were still having the risk for cardiovascular events or death especially the high-risk patients.

Our data showed success rates in achieving LDL-C targets by risk group as follow : $73 \%$ for low-risk group, $43.6 \%$ for high risk group and $14.8 \%$ for CHD groups. The success rates in the US L-TAP study were $68 \%, 37 \%$ and $18 \%$ for low-risk, highrisk and CHD patient groups respectively. Hoerger et al has found from the National Health and Nutrition Examination Survey III phase 2 that the success rates to reach LDL-C target level were $63 \%, 55.4 \%$, and $17.5 \%$ for low-risk, high-risk and CHD patient groups respectively. ${ }^{17}$ In line with the US-studies mentioned above, our study has shown that the more the cardivascular risks they had, the lower the likehood of dyslipidemic patients reaching the LDL-C target levels.

In this study, $76 \%$ of patients received statins, $21 \%$ fibrates, $1 \%$ combination drugs and the remaining $2 \%$ non-pharmacological therapy. It is clearly shown that most physicians prescribed statins as their preffered lipid-lowering drug. Unfortunately most of the patients received low dose or the starting dose recommended for each statin did not receive the dosage frequently used in clinical trails. The mean LDL-C levels after treatment in patients who did not reach LDL-C targets, was even higher than the recommended level to start therapy. The means of LDL-C level after treatment in high-risk group and CHD patients were $162 \mathrm{mg} / \mathrm{dL}$ and $158 \mathrm{mg} / \mathrm{dL}$ respectively. This clearly showed that their initial LDL-C levels were high. Cullen et al stated that a "log-linear" correlation exists between statin dosage or more-effective statin is needed to lower cholesterol level adequately in high-risk patients compared to the low-risk patients. ${ }^{18}$

The efficacy of statin therapy in both primary and secondary prevention reducing CHD mortality and other CHD events has been established by some mega trials. In this study, there were significantly more patients treated with statins who reached LDL-C target goals compared to patients treated with fibrates. It is not surprising since statins has been known to be more effective than fibrates in lowering toato cholesterol and LDL-C level, whereas fibrates were more effective in lowering triglyceride and increasing HDL-C level. In NCEP and European Atherosclerosis Society (EAS) recommendations, it was suggested to use fibrates in hypertriglyceridemic patients.

In the present study, 1082 patients received HMG CoA-reductase inhibitor monotherapy, which included various doses of fluvastatin, lovastatin, pravastatin, simvastatin and atorvastatin. The success rate of atorvastatin was significantly higher than other statins, whereas in the US L-TAP study, simvastatin was the most effective drug (atorvastatin was not commercially availabel at that time). In the US LTAP study, the success rates were $15.3 \%$ for fluvastatin, $22 \%$ for lovastatin, $24.4 \%$ for pravastatin and $38.3 \%$ for simvastatin.Hunninghake prospectively compared 344 patients without CHD who were treated with various statins and found that the success rates at week-12 were $16 \%$ for fluvastatin, $34 \%$ for lovastatin, $41 \%$ for simvastatin and $71 \%$ for atorvastatin. $^{19}$ In our study, success rates for atorvastatin was $93.4 \%$ in low-risk patients, and $76.5 \%$ in high-risk patients. Both were statistically significant to other statins. In CHD patients, success rate for atorvastatin was $31 \%$ only, but there was no significant differences to other statins. This might be due to small number of patients in this group. In the United States, Brown studied 318 patients with CHD and compared the results prospectively among statin groups. In week-12, the success rate of atorvastatin to reach LDL-C target level was $32 \%$. This was significantly higher than fluvastatin $(1 \%)$ and lovastatin $(12 \%)$, but not significantly higher than simvastatin $(22 \%)$.

Only $14 \%$ of physicians who participated in this study indicated that they were aware of NCEP guidelines. This percentage is much lower than investigators awareness in th US L-TAP study which 
was $95 \%$. Contradictory, the overall success rate in achieving the LDL-C targets is higher in Indonesia than in the United States ( $48.8 \%$ vs $38 \%$ ), this may be due to the fact that many patients in this study (39\%) received atorvastatin while no patient received atorvastatin in the US L-TAP study.

The results of this survey as presented here do not meet the classical criteria of a randomized, controlled clinical trial. Hence, no comparison can be made on the efficacy of different drugs used on this survey. However, this study mimics the real-life situation and provides information about practice of physicians in treating dyslipidemia.

In conclusion, this study revealed that the majority of dyslipidemic patients treated in routine clinical practice did not reach the NCEP target goals. The success rates were even lower in high risk patients and lowest in CHD patients. This was probably due to the lack of the understanding of the treating physicians with regard to the NCEP/PERKI guidelines and to the in adequate dosages of lipid modification drugs used in this survey.

\section{Acknowledgements}

The authors wish to thank all the doctors in 13 cities who participated in this study and to PERKI which endorsed this study.

\section{REFERENCES}

1. Frick MH, Elo O, et al. Helsinki Heart Study : Primary prevention trial with gemfibrozil in middle-aged men with dyslipidemia.N Engl J Med $1987 ; 317$ : 1237-45

2. Castelli WP, Garrison RJ, et. al. Incidence of coronary heart disease and lipoprotein cholesterol levels. The Framingham Study. JAMA 1986; $256: 2835-8$

3. Lipid Research Clinics Program. The Lipid Research Clinics Coronary Primary Prevention Trial I : Reduction in the incidence of coronary heart disease. JAMA 1984; $251: 351-64$

4. Neaton JD, Blackbum $H$, et. al. Serum cholesterol level and mortality findings for men screened in the Multiple Risk Factor Intervention Trial. Arch Intern Med 1992; 152: $1490-1500$

5. Shepherd J, Cobbe SM, et.al. For the West of Scotland Coronary Prevention Study Group. Prevention of coronary heart disease with pravastatin in men with hypercholesterolemia. N Engl J Med 1995; 333:1301-1307

6. Downs JR, Clearfield $M$, et. al. Primary prevention of acute coronary events with lovastatin in men and women with average cholesterol levels; results of AFCAPS/ TexCAPS. JAMA $1998 ; 279: 1615-1622$

7. The Scandinavian Simvastatin Survival Study Group. Randomised trial of cholesterol lowering in 4444 patients with coronary heart disease : The Scandinavian Simvastatin Survival Study (4S). Lancet 1994; 344 : 1383-1389

8. Sacks FM, Pfeffer MA, et.al. The effect of pravastatin on coronary events after myocardial infarction in patients with average cholesterol levels. Cholesterol and Recurrent Events Trials Investigators. N Engl J Med 1996; 335 : 1001-1009

9. Long-term Intervention with Pravastatin in Ischemic Disease (LIPID) Study Group. Prevention of cardiovascular events and death with pravastatin in patients with coronary heart disease and a broad range of initial cholesterol levels. N Engl J Med 1998; 339 : 1349 57

10. Expert Panel on Detection, Evaluation, and Treatment of High Blood Cholesterol in Adults. Summary of the second report of the National Cholesterol Education Program (NCEP) Expert Panel on Detection, Evaluation, and Treatment of High Blood Cholesterol in Adults (Adult Treatment Panel II). JAMA $1993 ; 269: 3015-23$

11. National Center for Health Statistics. Third National Health and Nutrition Examination Survey, 1988-94, US NHANES III Examination Data File.

12. Sueta CA, Petkun WM, et.al. Recommended management for hyperlipidemia and heart failure are we following the guidelines ? (abstract). Circulation 1997, 96 : Suppl 1 : 166

13. Ministry of Health Republic of Indonesia. National Health Houshold Survey 1992, Jakarta

14. Ministry of Health Republic of Indonesia. National Health Houshold Survey 1995, Jakarta

15. Pearson TA, Laurora I, et.al. The Lipid Treatment Assessment Project (L-TAP). A multicenter survey to evaluate the percentages of dyslipidemic patients receiving lipid-lowering therapy and achieving lowdensity lipoprotein cholesterol goals. Arch Intern Med $2000 ; 160: 459-467$

16. Schrott $\mathrm{Hg}$, Bittner V, et. al. for the HERS Research Group. Adherence to National Cholesterol Education Program treatment goals in postmenopausal women with heart disease; The Heart and Estrogen / Progestin Replacement Study (HERS). JAMA $1997 ; 277$ : 1281 1286

17. Hoerger TJ et.al. Treatment patterns and distribution of low-density lipoprotein cholesterol levels in treatment eligible United States adults. Am J Cardiol 1998; 82 : 6165

18. Cullen A et.al. Lipoproteins and cardiovascular risk-from genetics to CHD prevention. Eur Heart J 1998; 19 (Supp.C) : $\mathrm{C} 5-\mathrm{C} 11$

19. Hunninghake DB, Bakker-Arkema RG, et.al. Treating to meet NCEP-recommended LDL-Cholesterol concentrations with atorvastatin, fluvastatin, lovastatin, or simvastatin in patients with risk factors for coronary heart disease. J Fam Pract 1998 ; 47 : 349-356 